\title{
近世相模国大山寺における十二坊と御師の建築について EARLY-MODERN ARCHITECTURE FOR JUNI-BO AND OSHI IN OYAMA-DERA TEMPLE OF SAGAMI-NO-KUNI PROVINCE
}

\author{
山岸吉弘*1
}

\section{Yoshihiro YAMAGISHI}

\begin{abstract}
This paper aimed to recover the outline and analyze the characteristics of the mansions of Juni-bo (twelve branch temples) in Oyama-dera temple precinct in Kanagawa province, and the houses of Oshi priests in its temple town by collecting and comprehending relative historical materials. It focused on the end of Edo and the beginning of Meiji periods to consider from the perspective of architectural history. Consequently, the mansions and the houses had their own characteristics along with interactive elements. The mansions held Buddhist services, whereas the houses accommodated Danka pilgrims, both functions being shared in both buildings.
\end{abstract}

Keywords : the pre-modern period, sagami-no-kuni province, mansions, houses 近世, 相模国, 屋敷, 住宅

\section{1. 相州大山の屋敷と住宅}

神奈川県中西部に広がる丹沢山地の東端に位置する大山は、別名 に阿夫利山とも称され、古くから信仰の対象ともなった。山内には 大山寺が境内を構え、山頂には阿夫利神社が石尊大権現を祀り、い ずれの創建や起源は古代にまで遡るという。下って近世に入り、幕 府の庇護の下で伽藍が再興され、別当の八大坊を中心に十二坊から なる自治のための運営機関が組織された ${ }^{1)}$ 。また、同時に大山を聖 域と定める結界が張られ、在来の修験者は下山して「御師」となり、 参道に居住することで門前町が形成された ${ }^{2)}$ 。江戸時代の寺内や門 前の様相は、家康の主導によるこれら一連の「山内改革」を出発点 として幕末まで展開することになる（図 1)。

江戸時代における大山の最大の特徵は、御師と檀家からなる「大 山参り」と呼ばれる現象が江戸を中心に関東一円で流行したことで ある ${ }^{3)}$ 。盛時には 100 万人ともいわれる人々が大山を信仰し、各地 で講が結成され代参を立てては大山寺を参詣している ${ }^{4)}$ 。それら講 中は「檀家」と呼ばれ、特定の御師に引率されて登拝する（これを 檀家の「坊大り」という)。また、御師の活動の一つに、関東一円に 散在する檀家を順次に訪れ、配札や祈䘠などを行った。大山と地域 を繋ぐ経路である大山道を開発し、名主など有力者の協力を得ては、 「定宿」と呼ばれる檀家宅を拠点に定めて巡回した（これを御師の「檀 回り」という)。このように、御師と檀家の双方が広範囲を移動す ることによって機能する動的な社会構造が成立していた ${ }^{5)}$ 。御師は、 寺院と檀家を取り持ち媒介する役割を担う。大山寺の配下にある神 職者で、聖域と俗界の中間に存在し、最盛期には执よそ百六十五軒 の御師が、門前町に居宅を構え活動していた ${ }^{6)}$ 。

本稿は、大山寺の寺内及び門前における十二坊の屋敷や御師の住
宅について、関連する史料の収集と読解を通して建物の概要を復元 し、特徴を分析することを目的とする ${ }^{7)}$ 。「大山詣り」が隆盛を迎え た江戸時代後期以後、幕末 ・明治期に焦点を当て、建築史学的な考 察を試みる ${ }^{8)}$ 。

収集した史料から、特に屋敷や住宅の形態を直接的に知ることの できる図面類を選定し、建物の具体像を把握する。それらの多くは 平面を描いた指図であり、建物の構成を知ることができる。また、 建築する過程で必要になる設計・積算・施工などの文書も残されて おり、建物を復元する上での手掛かりとなる。屋敷や住宅の概要を 整理した上で、特徴的な要素を抽出・分析する ${ }^{9)}$ 。

\section{2. 屋敷と住宅の概要}

考察の対象として、「手中家資料」と「高尾家文書」から合計 8 件 の屋敷や住宅を選定することができた ${ }^{10)}$ 。その内訳は、十二坊の筆 頭にある別当の八大坊上屋敷（上寺）、十一坊である供僧の大覚坊客 殿 - 中之院客殿 - 常円坊勝手 - 授得院勝手 - 広徳院庫裏、御師の高 尾家住宅・成田家住宅である。以下、個別に指図の内容を確認する。 $2-1$. 八大坊

八大坊は大山寺の別当で、慶長の改革に際して山内の整理を家康 に命じられて以来、寺院の中心的な存在にあった。修法のための上 屋敷（上寺）と経営のための下屋敷からなり、前者は山上の仁王門 脇に、後者は山下の福永町に、それぞれ設けられた。その内、上屋 敷を描いた二点の指図 $[1-\mathrm{A} ・ 1-\mathrm{B}]$ が残されており、建物の 概要を知ることができる（図 $2 \cdot 3$ )。

指図 $[1-\mathrm{B}$ ］には、<八大坊様上屋敷地割＞と表題されている。 <安政二年ノ三月より安政三年十一月迄二造作出来申候 $>$ とるこ 


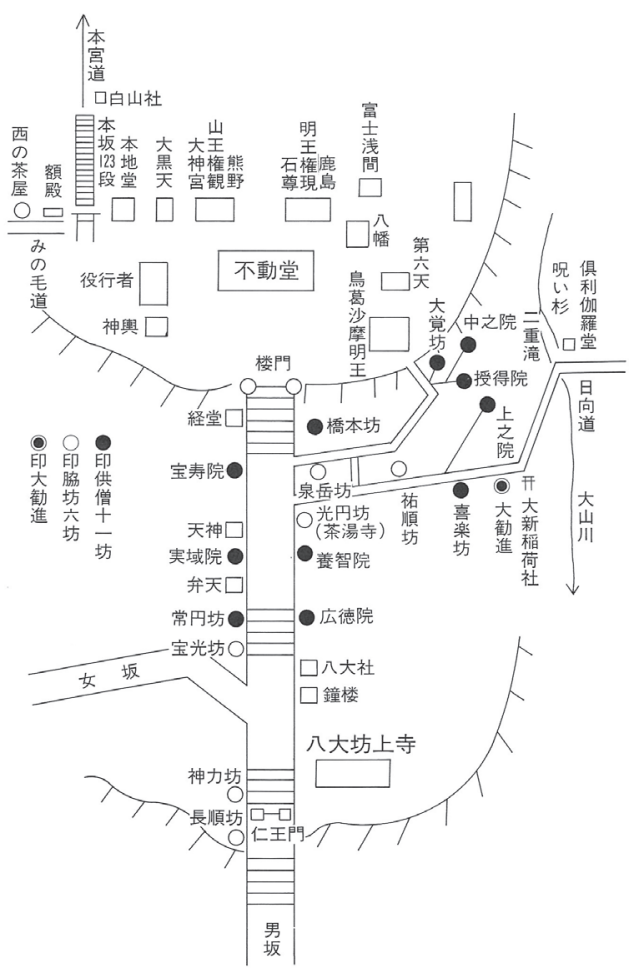

Fig.1 Plot plan of the Oyama-dera temple precinct ${ }^{28)}$ 図 1 大山寺諸堂諸坊配置図
とから、足掛け 十九ヶ月の期間 をかけて工事が 行われたようで ある。指図 $[1$ - A ]には、<八 大坊上寺地割 扣>と表題があ り、同じく上屋 敷（上寺）が描 かれている。指 図 $[1-\mathrm{B}]$ と 大きく代わると ころはないが、 指図 $[1-\mathrm{A}]$ には間取りや寸 法などを検討す る記述があるこ とから、製作年 代の前後関係を 推定することが できる。

屋敷の構成は大まかに表向きと内向きに区別され、その中間に土間 が位置している。当初、手前には＜八畳＞の部屋を田の字型に四つ配 置する計画であったが、その後、二つの部屋の広さを十畳に改めてい る。四つの部屋の内、表に面した一つの十畳の部屋が＜玄関＞で、正 面には＜大床＞を設ける。玄関の奥は＜仏壇＞を置く仏間となるが、 玄関と仏間の境界は＜ハリツケ>の壁が建てられており、直には接続 していない。玄関から仏間までに至るには、途中にある二つの部屋を コの字に通ることになる。玄関の隣室は＜使者之間＞として設けられ、 使者の間と仏間の間は更に一つの部屋で隔てられている。玄関と使者 の間の境は＜シ>として障子を立てるが、使者の間から仏間までの部 屋の境には＜カラ>として襖を用いる。仏間には仏壇の前が一部で板 敷きのように描かれているが、或いは護摩檀など雛壇状の仏具が置か れていたとも考えられる。

指図 $[1-\mathrm{A}]$ では、隣接する玄関や仏間は共に八畳であり、同じ 柱筋に取り付く車寄せも二間の幅として計画されているが、線を引き 足して修正し、全体的に拡張している。その結果、指図 $[1-\mathrm{B}]$ に 描かれるように玄関も仏間も十畳に広げられ、車寄せも二間半となっ た。

奥は主に四畳から八畳までの広さを有する部屋により構成されてお り、例えば最奥に並ぶ二つの部屋は＜トコ・タナ>の座敷飾りが設え られたり炉が切られたりするく御居間 $>や<$ 納戸部屋 $>$ な゙で、住持 など寺僧の生活の場として作られている。また、<拾八畳>の畳敷き に一畳ほどの大きさの囲炉裏が設けられたく上台所 >が併設する。

はす向かいに位置する表向き部分と内向き部分の間には、大きな筐

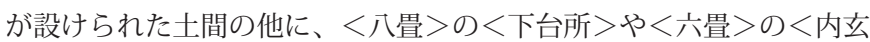
関>が位置する。上台所に接する下台所には焚き口が三つの酉があり、 障子で仕切られた十畳ほどの板敷きが隣接する。また、土間には<流 シ>やく水盤＞が置かれ、焚き口が二つの笡も作られる計画があった
ようである。それら土間や台所には、玄関の脇にある内玄関からくカ ラ＞の襖やくスキト >の杉戸を開けて入ることができる。

屋敷への出入り口として、<玄関 $>$ と $<$ 内玄関 $>$ 二種類の玄関 が設けられている。玄関には唐破風をあげた車寄せが付き床を設け 格式を重んじるが、内玄関にはない。また、玄関からは使者の間な どの前室を経て仏間に至るように計画されているが、内玄関からは 土間の脇を抜け下台所へと続き奥の日常生活の場へと導く。このよ うに、二つの玄関の差異は建物内へと引き込む動線にも現れている。

土間の端にある $<$ 物置 $>$ 前には、<入口 $>$ と <出口 $>$ が向かい 合って設けられている。大口は内玄関の前を通って土間に入るよう に作られている。出口の先には物置きの外側を䍛るように作られた 通路があり、石垣の脇を下りてゆく階段がある。つまり、敷地の外 へと続いているのだろう。大口から出口へ、人の流れが明確に意図 されている。

\section{$2-2$. 大覚坊}

大覚院は十一坊の内の一つで、八大坊を中心とする寺内組織の一 翼を担う供僧である。不動堂前の楼門に上る階段脇の路地を入った 先に、大覚坊は屋敷を構えた。屋敷を描いた四点の指図 $[2-\mathrm{A} ・ \mathrm{~B}$ ・ C・D］が残されている（図 $4 \cdot 5 \cdot 6 \cdot 7 ） 。$

一つ目の指図 [2-A］は、<大山寺大覚坊住居絵図 $>$ として敷 地を含めた屋敷の全体が描かれている。指図と共に作成されたく大 覚坊普請注文書 $>$ には＜电＞と記されているおり、万延元年 （1860）以前であることが分かる。二つ目の指図 [2-B］には、 <大山寺大覚坊様御客殿地割 $>$ として略図が描かれ、<文年年 ${ }^{2}$ 戌四 月吉日依リ図之ヨ $>$ の日付と、<但シ四拾三坪半外二便所壱ヶ所玄 関別二積ル＞として建物の大きさ等が書き込まれる。三つ目の指図 [2-C ］には、同じく「大山寺大覚坊様御客殿地割」と表題され、

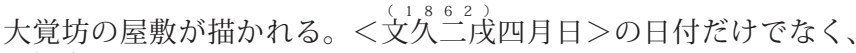
$<$ 䀼 286 月廿三日作事朱引分直ル $>$ とあるように 6 年後に改変を計画 しており、<棟梁手中明王太郎景元代控図 但シ御坊壱枚差上候>の 作成者が記される。四つ目の指図 [2-D］には「大山寺大覚坊様 地割」として、部分的ではあるけれども比較的に詳細な指図が描か

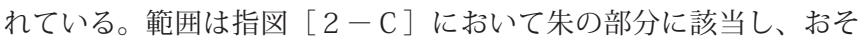
らくは改変を検討したものである。

屋敷は大まかに手前と奥からなり、前者には＜下台所 $>$ しくは <勝手 $>$ のある内向き部分に、後者には＜須弥壇 $>$ に<宮殿 $>$ も くは＜本尊 $>$ が置かれる表向き部分に、それぞれ区別される。手前 の内向き部分は何れの指図をみてもおよそ変わるところはなく、く大 戸口 $>$ を入って直ぐの $<$ 土間 $>$ と $<$ 拭板 $>$ を敷く下台所（勝手）と <イロリ>を設けた＜惣二階作 $>$ の大庫裏 $>$ がある。土間や下台 所と大庫裏の境には＜せうし >など障子を立てるが、土間と下台所 を隔てる装置はなく連続している。

奥は手前の部分に比べて多くの部屋から構成されており、指図ご とに修正が加えられ、複雑である。始めに描かれたであろう指図 $[2$ －A］によると、宮殿が祀られくコマダン >を置く<八畳敷 $>$ を最 深部として、大口となる $<$ 式台 $>$ から順次に $<$ 玄関・取次間・次・ 書院 >と各部屋が続く。玄関の脇には＜小玄関＞があり、二つの異 なる玄関が用意されている。次や小立関に隣接して<茶之間 $>$ が設 けられ、<こしせうし >もしくは＜フスマ>により接続されるが、 護摩檀のある八畳敷きとの境には＜(ハリツケ) カヘ>で隔てられる。 


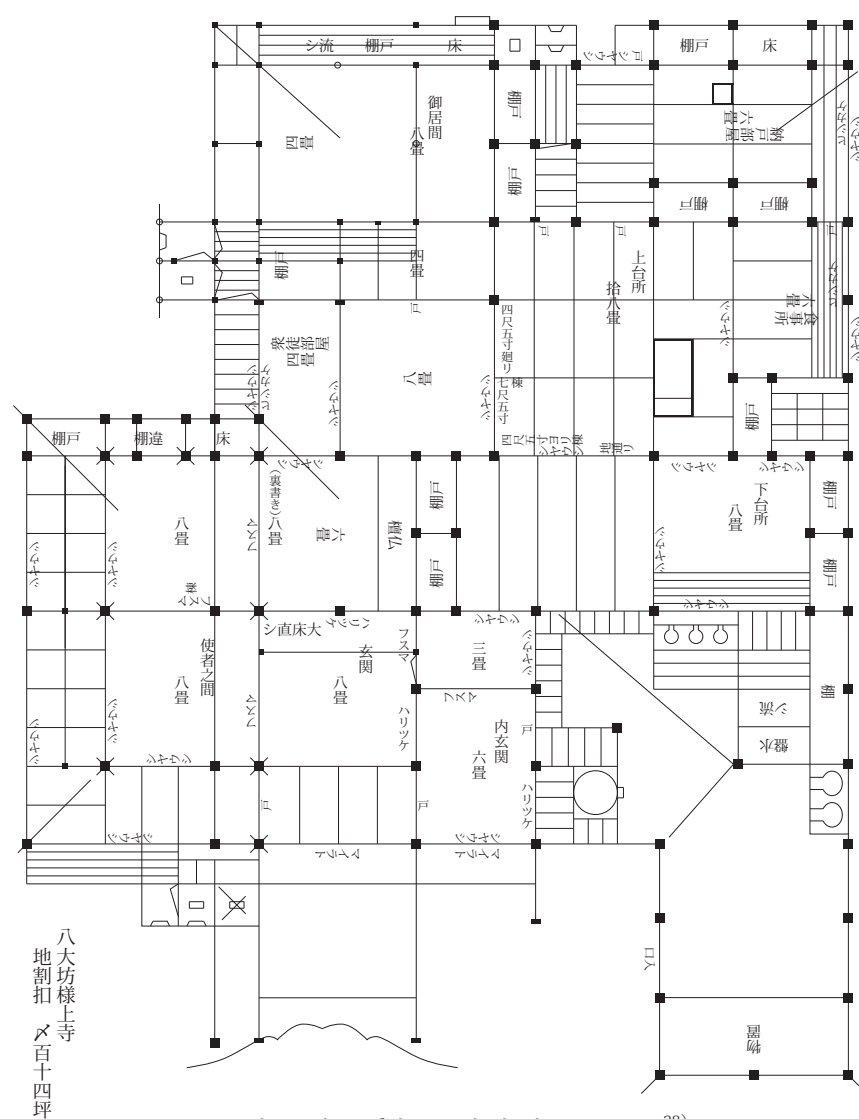

Fig.2 Floor plan of the Hachidai-bo mansion ${ }^{28}$

図 2 八大坊屋敷指図 [1 - A ]

指図 $[2-B]$ では奥の部分に相違が見られ、本尊を祀る<拝所 $>$ を含め、<上之間・次之間・三之間 $>$ の四つの部屋を田の字型に並 べている。拝所を最上位に、三之間を最下位に、空間の格式はコの 字型に階層を形成している。その他、次之間に隣接して唐破風を上 げた＜玄関＞から続く部屋や、＜床＞を設けた＜御居間 > がある。 指図 $[2-\mathrm{C}]$ では、奥の部分を朱で記述し描画しており、指図 $[2$

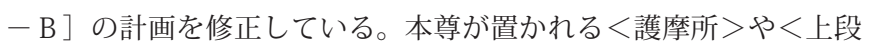
之間・二之間・茶之間 $>$ の位置は変わらないが、三之間の部屋の名 称を茶之間としている。また、玄関前の部屋をくハリツケ $>や<フ$ スマ>で仕切り、或いは縁の部分に張り出して増設し、＜溜之間 $>$ を含む三つの部屋を新たに設けている。つまり、指図 $[2-\mathrm{B}]$ か ら指図 $[2-\mathrm{C}]$ への変化は、三之間・次之間・上之間・拝所から なるコの字型を、溜之間・二之間・上段之間・護摩所からなる L 字 形へと構成を修正しているといえよう。コの字型では、出発点とな る三之間が玄関などから遠くなって動線が複雑になる。指図 $[2-\mathrm{D}]$ では、く二之間 $>$ 前後に区切り、十畳と五畳の二つの部屋に分け ている。更に、玄関の位置をずらして上段之間や二之間と揃え、部 屋の並びを直線的に配置し直し、動線をより簡明にしている。

指図 [2-A］には周辺の様子も含めて記録されており、前面の 路地が＜坂＞となっていることからも分かる通り、敷地は傾斜地に ある。そのため、左右には石垣が描かれる。上方は＜不動御堂之方 $>$ であり、下方は＜坊中屋敷 $>$ として寿徳院がある。また、坂を隔 てた向かいの $<$ 坊中屋敷 $>$ や裏の $<$ 坊中屋敷 $>$ は、それぞれ橋本坊 や中之院と考えられる。坂と敷地の境には＜御門 >が建てられ、玄 関まで石畳を敷く。また、路地に接する建物の部分にはそ戸二 $>$ と して戸を立てて、敷地の内外に出入りすることができるようになっ

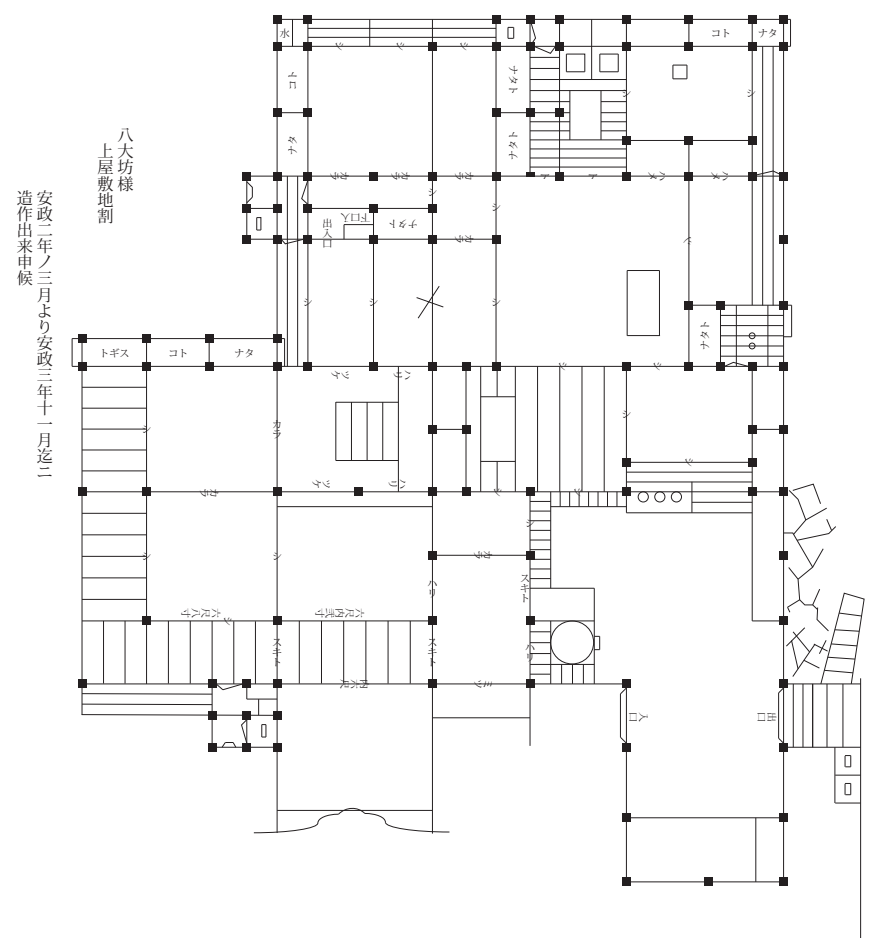

Fig.3 Floor plan of the Hachidai-bo mansion $\overline{28)}$ 図 3 八大坊屋敷屋敷 $[1-\mathrm{B}]$

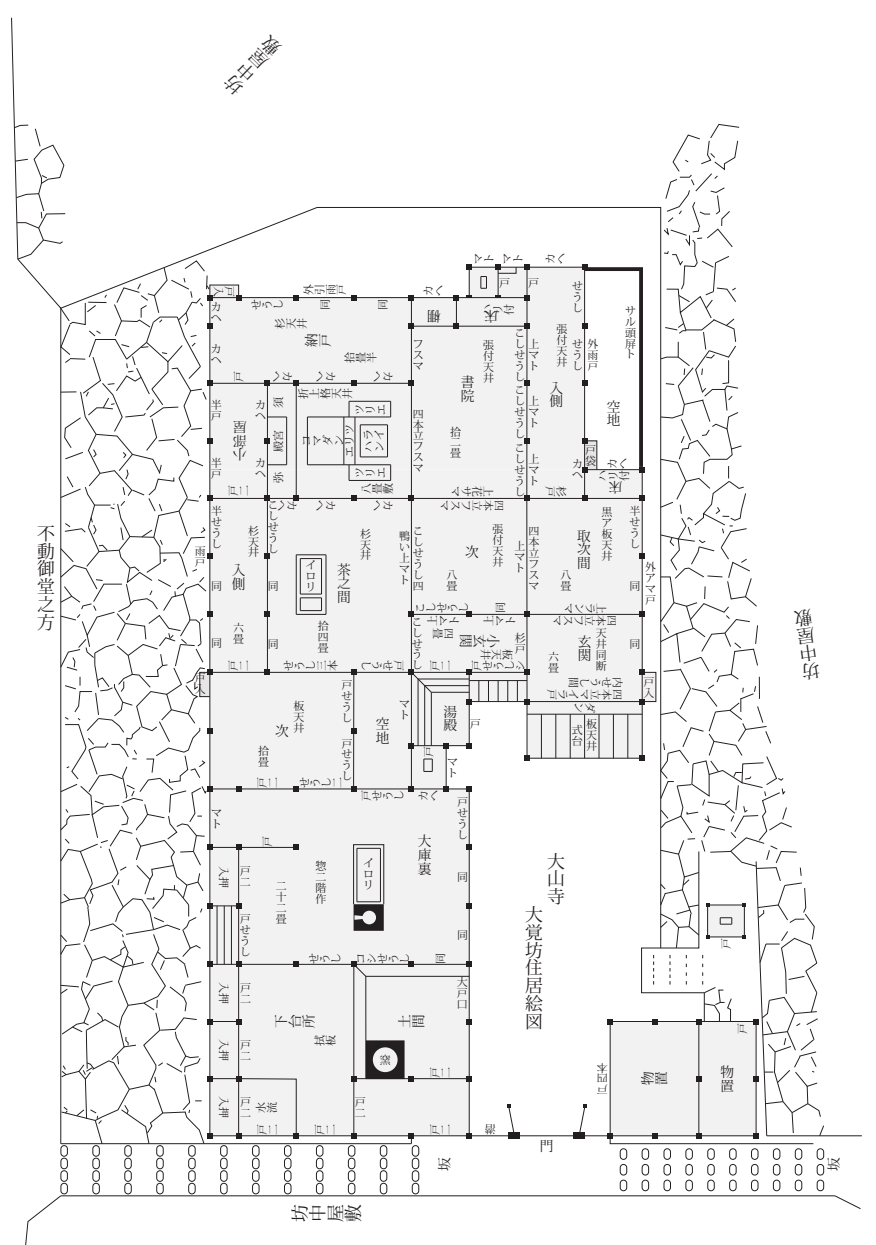

Fig.4 Floor plan of the Daikaku-bo mansion ${ }^{28)}$ 図 4 大覚坊屋敷指図 $[2-\mathrm{A}]$ 


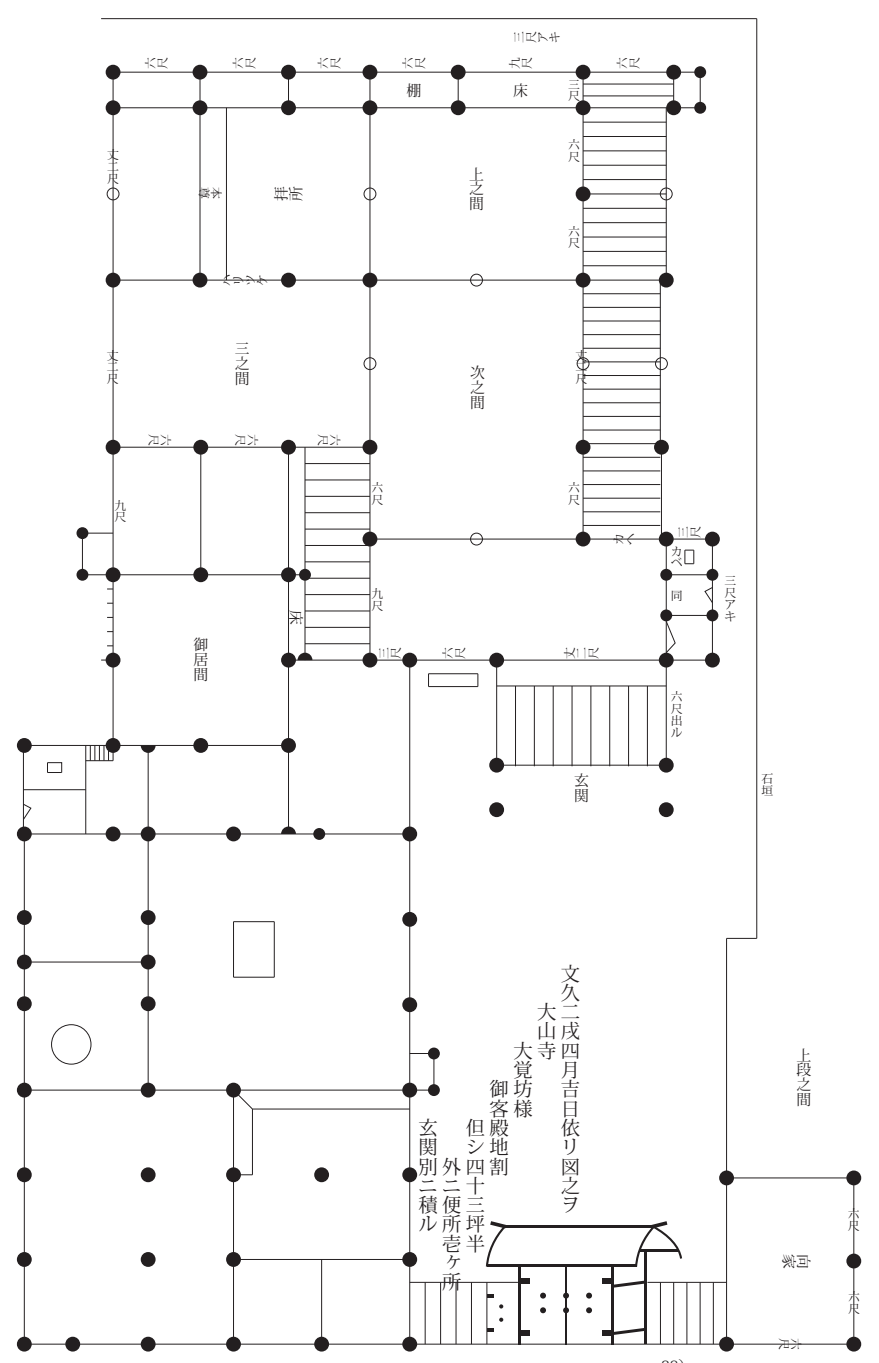

Fig.5 Floor plan of the Daikaku-bo mansion ${ }^{28}$ 図 5 大覚坊屋敷指図 $[2-B]$

ている。

$2-3$. 中之院

中之院は供僧十一坊の内の一つで、大覚坊の裏手に屋敷を構える。 中之院の屋敷を描いた三点の指図 $[3-\mathrm{A} \cdot \mathrm{B} \cdot \mathrm{C}]$ が残されてい る(図 $8 \cdot 9 \cdot 10)$ 。

一つ目の指図 [3-A］には「照海様代中之院様地割」として、 中之院の屋敷が描かれている。<安政五午四月廿三日>の日付の他 に、<手中明王太郎控 右之通リ弐枚出来壱枚之儀八御院主控 $>$ とあ り、大工用と施主用の 2 枚の指図が作成されたことが記されている。 二つ目の指図 $[3-\mathrm{B}]$ には「大山寺中之院様客殿地割御院主立合 ニテ定」の表題が付き、「地坪メ四拾四坪六分但シ六畳ノ便所共外二 御玄関ノ坪」の規模が明記される。また、く文久 ${ }^{8}{ }^{6}{ }^{2}$ 年戌ノ七月廿一 日改>から、施主である院主との相談の上で、4 年前に計画した内 容を修正するための指図であることが分かる。なお、く棟梁手中明 王太郎景元代作之此図別テ書御院主え壱枚差上置候＞とあるように、 大工と施主に一枚ずつ、計二枚の指図が作成されている。三つ目の 指図 $[3-\mathrm{C}]$ には「中之院様地絵図控」として中之院の屋敷では あるが、他の指図のように屋敷全体を描くのではなく、仏間のある 座敷が中心となっている。また、年代が不明であり、他の二つの指 図との時間的な前後関係も明確でない。

屋敷の構成は大まかに手前と奥に区別され、中間には廊下を通し

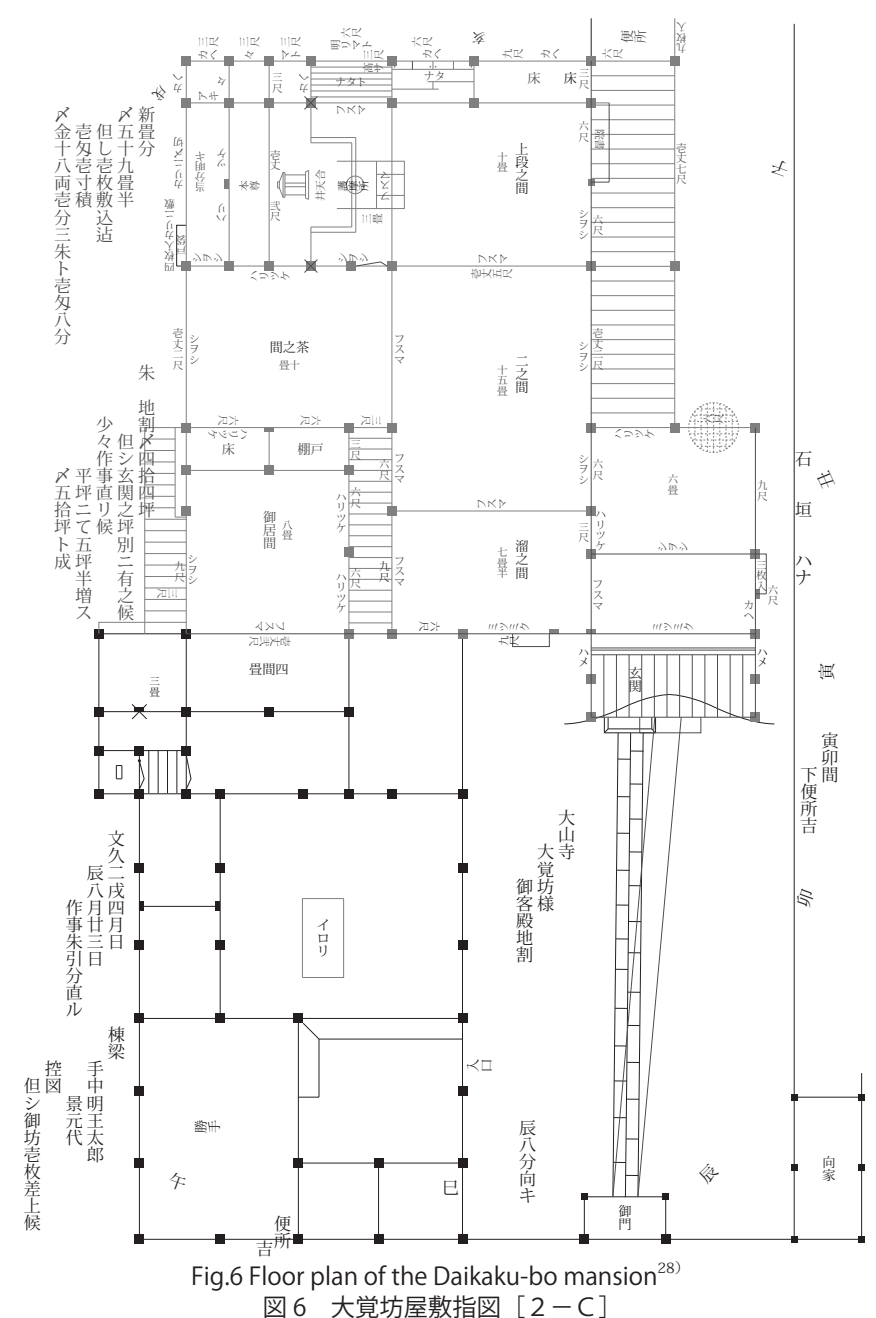

て両者を隔てる構成は、いずれの指図をみても変わらない。一方で、 手前の部分は改変の前後で内容が大きく異なる。安政 5 年 (1858) の指図 [3-A］によると、手前には＜仏間＞を中心とする六つの 部屋からなり、前後 2 列で長方形に整然と配置されている。前には ＜拾畳＞が三つ並び、後ろには＜八畳・六畳・四畳＞が並ぶ。三つ の十畳の内、火灯空が二つ付く部屋は＜茶之間 $>$ であり、八畳は $<$ 上 檀 $>$ として作られる。また、建物の西側を通り門を潜って四畳に至 るく中庭入口 >があるだけでなく、十助の手前には板敷きを介して ＜玄関 >と<小玄関 >が設けられている。また、板敷きの突き当た りに<六畳 $>$ 部屋がある。玄関から入り、板敷き・十畳を経て仏 間へと至る直線的な動線を想定することができる。

文久 2 年（1862）の指図 [2-B］によると、六つの部屋からな る構成はそのままに玄関の位置を変えるなど、安政 5 年（1858）に 立案した計画を変更している。かつて茶之間であった部屋の規模を 十畳から<拾五畳 $>$ に拡張し、小玄関のあった場所に<玄関 $>$ を移 動させている。従って、玄関から仏間への動線は、鍵の手に曲がる ことになる。また、玄関のあった場所には板塀を巡らし、冠木門を 設置し、塀や門で囲い込まれた先にあったかつての六助は、<茶座 敷〉となっている。

奥の部分は二つの指図で異ならず、＜大戸入口 >を大って直ぐの 部屋は＜炉・イロリ >や䇴を設ける／勝手 $>$ であり、更に内部に入っ

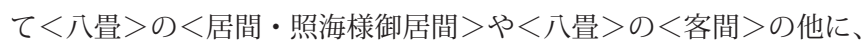
$<$ 二畳 $>$ の $<$ 小僧部屋 $>$ や $<$ 納所部屋 $>や<$ 奥部屋 $>$ な゙が設けら 


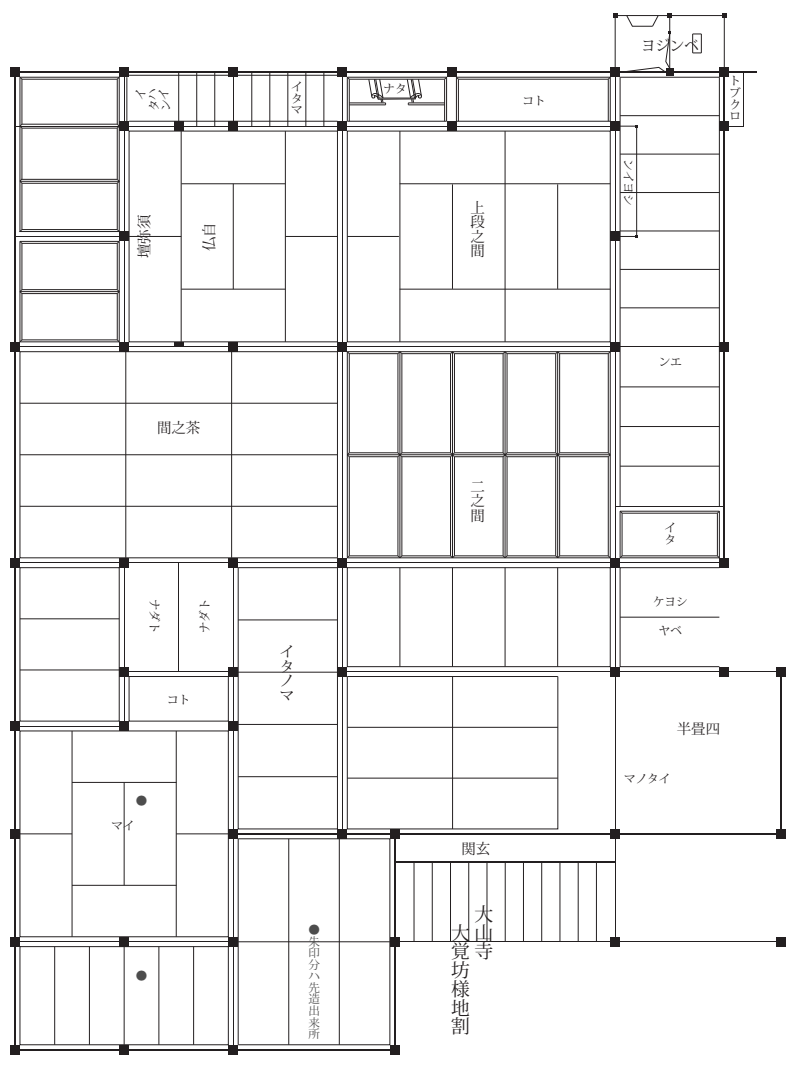

Fig.7 Floor plan of the Daikaku-bo mansion ${ }^{28}$ 図 7 大覚坊屋敷指図 $[2-\mathrm{D}]$

れる。

年代不明の指図 [ $3-\mathrm{C}$ ］は、仏間を中心とする手前の部 分のみを描く。六つの部屋の中央に<須弥壇 $>$ のることや、 ＜玄関 $>$ の位置などは類似するものの、部屋の名称や構成に特 徵があり、他の指図と異なる点も多い。須弥壇の前に位置する <室中ノ間 $>$ と < 上段之間 $>$ は隣接するも<カへ $>$ で仕切られてい る。上段之間から<二ノ間・三八間・溜ノ間 $>$ と続き、玄関へと至る。 また、〈イロリ>を備えた広いく茶之間＞が設けられ、脇には修行 僧が詰めていたであろう＜所化寮＞の小さい部屋が置かれる。更に、 他の二つの指図では奥の部分にあった居間は、位置関係はそのまま に<上段之間 $>$ の裏に<御居間 $>$ として用意されている。玄関から

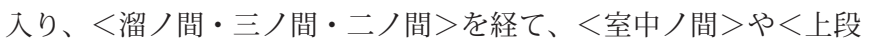
之間 $>$ と至る、横方向と縦方向の動線が明瞭である。<湯殿 $>や ~$ ＜空地 $>$ の奥に＜大戸口＞を開ける＜土間＞や＜台所＞が位置して おり、奥の部分より手前の部分に多くの機能を振り分けている。

$2-4$. 常円坊

常円坊は十一坊の一つで、女坂を過ぎた参道の脇に屋敷地がある。 指図 [4] には<元大山寺常円坊勝手 >として常円坊の屋敷が描か れるも、勝手とある通り内向きの作業場のみであり、座敷等の居室 は含まれない（図 11）。

勝手は、長辺 8 間半と短辺 4 間の長さからなる長方形で喰違の平 面構成を採り、板の間を介して助敷き部分と土間・板敷き部分に区 分される。前者は、一番小さな部屋である $<$ 四畳 $>$ から<イロリ $>$ を置いた広い＜拾五畳 $>$ までの数部屋からなる。後者は、〈入口 $>$

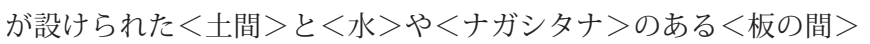
に加え $<$ 風呂場 $>$ が用意されている。

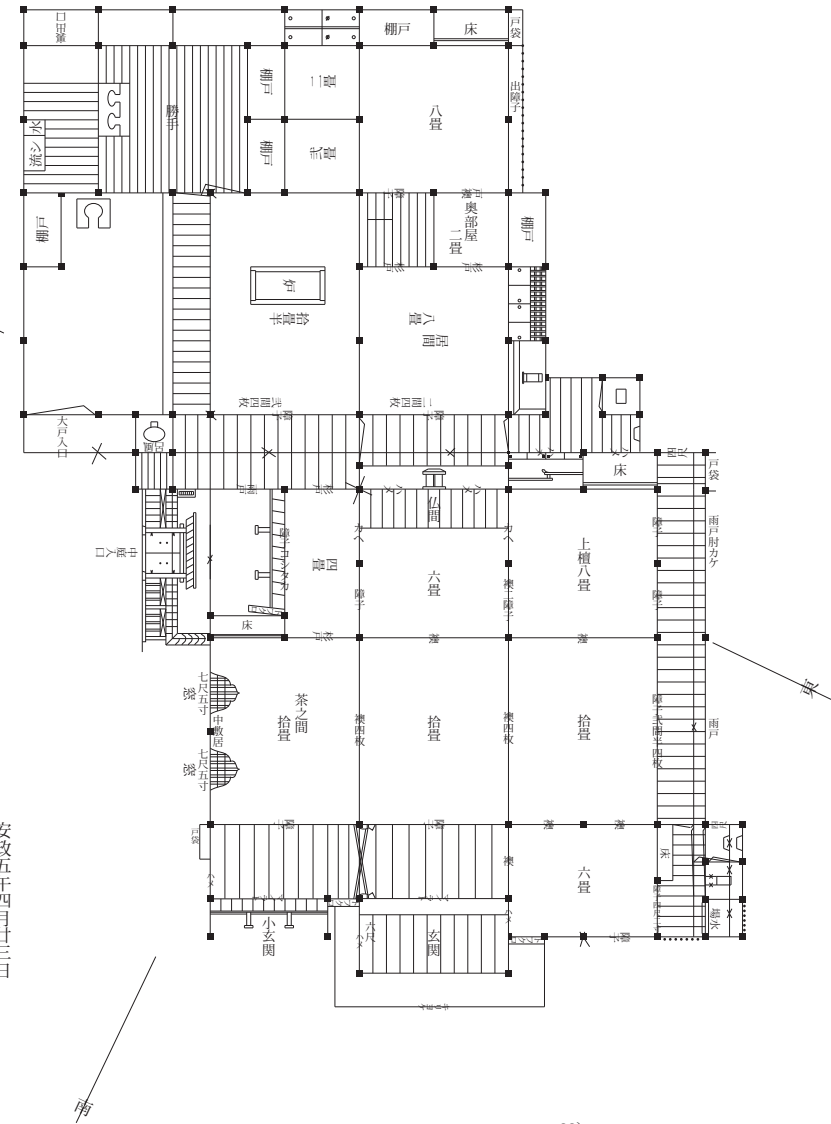

Fig.8 Floor plan of the Nakanoin mansion ${ }^{28}$

図 8 中之院屋敷指図 $[3-\mathrm{A}]$

\section{$2-5$. 授得院}

授得院は十一坊の一つで、屋敷地は大覚坊に隣接する。指図 [5] には $<$ 元大山寺授徳院勝手求之 $>$ とて授徳院の勝手部分のみが描 かれる(図 12)。また、 $<$ 明治二百已九月吉辰 $>0$ 年月と $<$ 宗弁院之代 $>$ の院主が、それぞれ記されている。

建物は、長辺 8 間と短辺 4 間からなる長方形で喰違の平面構成で、 畳敷き部分と土間・板敷き部分からなる。前者は、くヒロリ>を有 する広い<拾八畳 $>$ を心に幾つかの部屋に分かれ、外に $<$ 風呂場 $>$

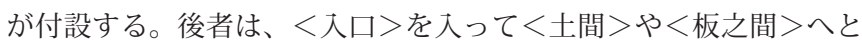
続く。勝手の内容はおよそ常円坊のそれと差異はなく、どちらも典 型的な作りのようである。また、畳敷き部分の先には<客殿取付之 所>とあり、屋敷の全体では勝手と客殿という構成であることが分 かる。

\section{$2-6$. 広徳院}

広徳院は十一坊の一つで、参道を隔てて常円坊の向かいに屋敷地 を構える。指図 [6] には＜広徳院様庫裏御住居絵図 $>$ として庫裏 の一階と二階が簡略化されて描かれている（図 13）。

一階は＜茶ノ間・台所・土間・小寮・雑庫 $>$ などからなり、土間 には二つの＜大戸口 >が設けられ、他に<茶間入口 $>$ もみられる。

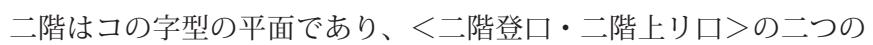
階段で上下階を繋いでいる。 


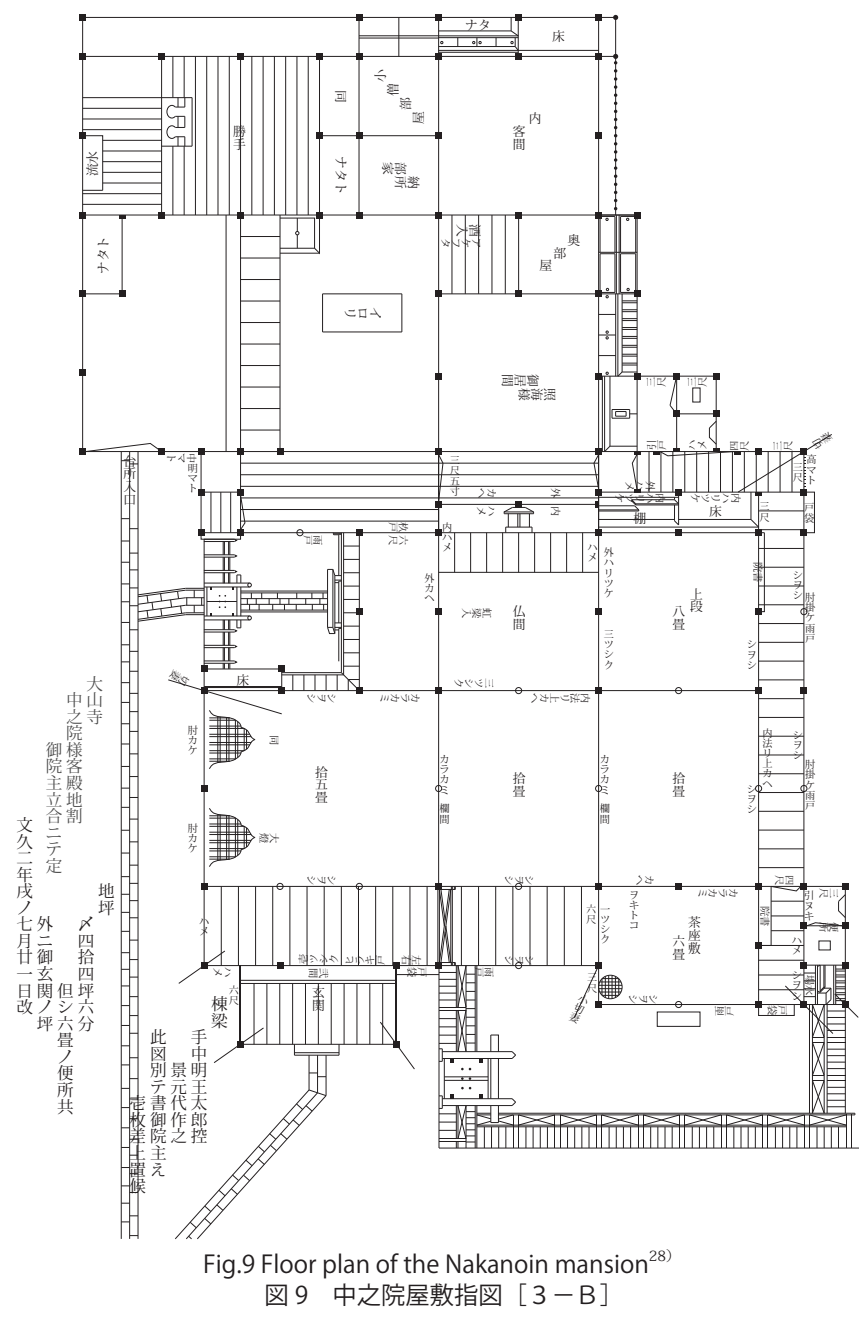

2-7. 高尾家

高尾家は御師であり、同家の屋敷を描いた二点の指図 [7-A・B ] は、「家作仕様積立帳」の中に含まれている（図 $14 \cdot 15$ )。仕様を踏 まえた費用を積算した文書で、表紙には＜文久四年甲子四月吉日 $>$ もしくは<元治元年甲子四月吉日 $>$ の年月を記す。どちらも同じ内 容の複製であり、〈地割但し七拾坪余〉の表題も付き、指図もおよそ 異ならないが、〈神殿＞の描き方のみ平面図もしくは立面図という 違いがある。

建物は、<長縁 $>$ に囲われた畳敷き部分とくイロリ>を備えた土 間・板敷き部分に区別することができる。前者は、更に二つの用途 が想定され、一つは宗教的な行為のための場であり、一つは日常的 な生活を送るための場である。宗教的な部分は、くトコ・タナ・書

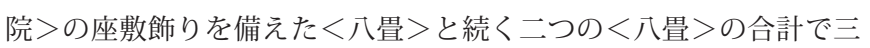
つの部屋である。日常的な部分は、<部家 $>$ とある<八鳁 $>$ を含め <六畳 $>$ から<十武鳁 $>$ までの広さからなる合計で四つの部屋であ る。部屋の広さを記述する文字の向きからも、それぞれの差異を理 解することができる。＜六畳＞には＜二階口＞が位置しており、お そらくは宿泊者の滞在の場であった二階へ上がることができる。ま た、敷地内には独立した建物として神殿が建てられており、平面図 や立面図から縁と接続していることや切妻平入りの三間社であるこ となどが分かる。後者は、おそらくは土間と板の間からなる作業空 間であり、<イロリ>や䇴が置かれる。土間には三つの開口部が設 けられ、表から直接に入るものと門の内側の敷地内から入るものの

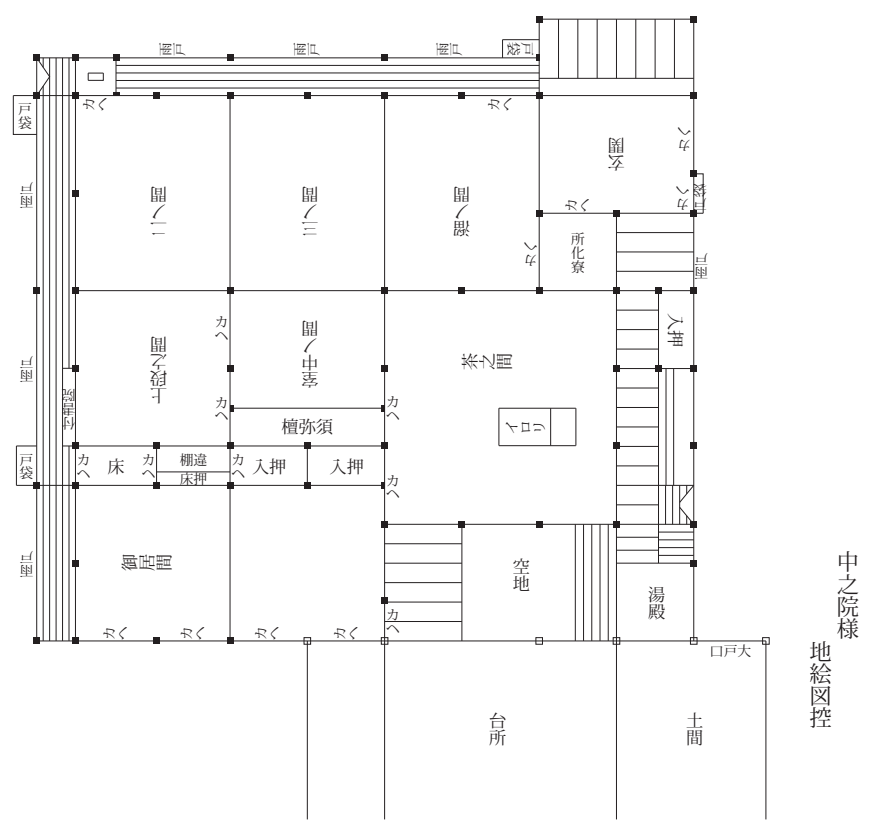

Fig.10 Floor plan of the Nakanoin mansion ${ }^{28)}$ 図 10 中之院屋敷指図 [3-C]

二つは＜入口 >であり、一つは＜出口 >である。

$2-8$. 成田家

成田家は御師であり、安政二年（1855）に同家の屋敷を手掛けた 明王太郎が雑録した文書の中に、材料の寸法・数量の控えや金銭の 授受の経過に加えて、簡単な指図 [8］が含まれている（図 16）。

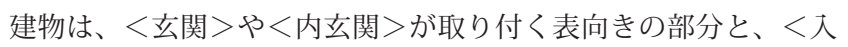
口>を大って直ぐ＜土間 $>$ となる内向きの部分と、大きく二つに区 分される。玄関には唐破風を上げ大きな式台を張り、〈七丈半 $>$ を 経て<二十二丈半 $>$ と至る。その先の縁には渡り廊下のようなも のが接続し、恐らくは祈祷や祓を行うための神殿や祠が安置されて いるのだろう奥へと続いている。内立関からは、表向きの<八畳 $>$ と内向きの<八丈 >のどちらへも入ることができるようになってい る。また、土間から入ると、左側には $<$ 二十四坪 $>$ 二階に上がる 階段が、右側には簡を備えた台所が、正面にはくフロ>や便所が、 それぞれ用意されている。また、䇴の脇には<出口>が設けられて いる。

\section{3. 屋敷と住宅の特徵}

個別に整理した屋敷や住宅の内容を踏まえ、始めに、十二坊の屋 敷と御師の住宅の特徵的な要素をそれぞれ明確にさせる。その後、 両者の類似点や相違点を検討する。

$3-1$. 十二坊の屋敷

表向きと内向きの区分

十二坊の屋敷に共通するのは、いずれも表向きと内向きの空間が 明瞭に区別されていることである。大きく二つの部分から全体が構 成されていることは、史料の表題に＜客殿 $>や<$ 勝手 $>$ などの名称 が使用されていることからも窺われる ${ }^{11)}$ 。例えば、八大坊や中之院 の屋敷は、表向きと内向きの部分を鍵の手に組み合わせており、そ れぞれが独立した二棟の建物のからなることが分かる。また、「立関」 と「(土間）入口」など表向きと内向きの空間に対応する出入り口が 存在するだけでなく、両者の境界部分には三つ目の出入り口として 
$<$ 内玄関 - 小玄 関・中庭入口> などが設けられ ており、双方の 内部に繋がり得 る中間の領域と 捉えることがで きる ${ }^{12)}$ 。

表向き空間の階 層

表向きの空間 は幾つかの座敷 が集合して形成 され、その内の 一つが仏壇を置 く仏間になって いる。十二坊 は勿論のこと、 十一坊も護摩を 焚いていたこと は、大覚坊の屋 敷にある<コマ ダン>からも明 瞭である。檀家 は御師の取り次 ぎにより、十二 坊から法要を受

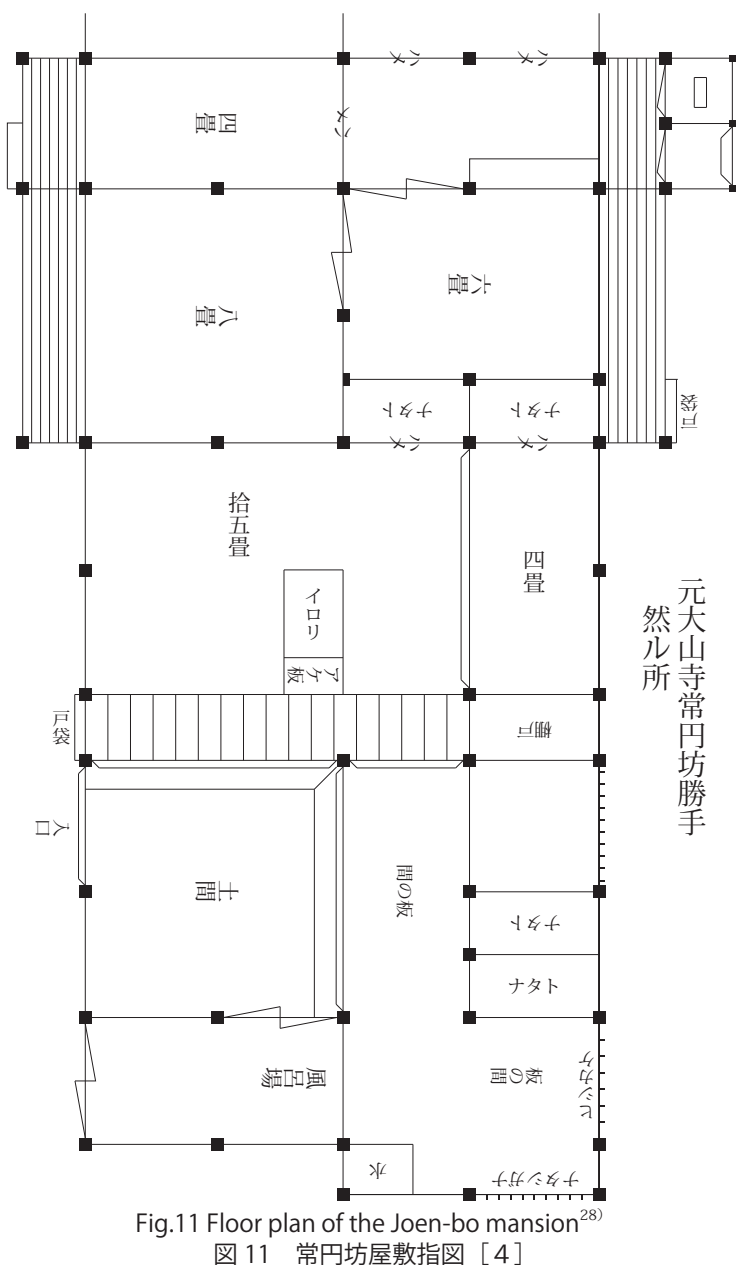

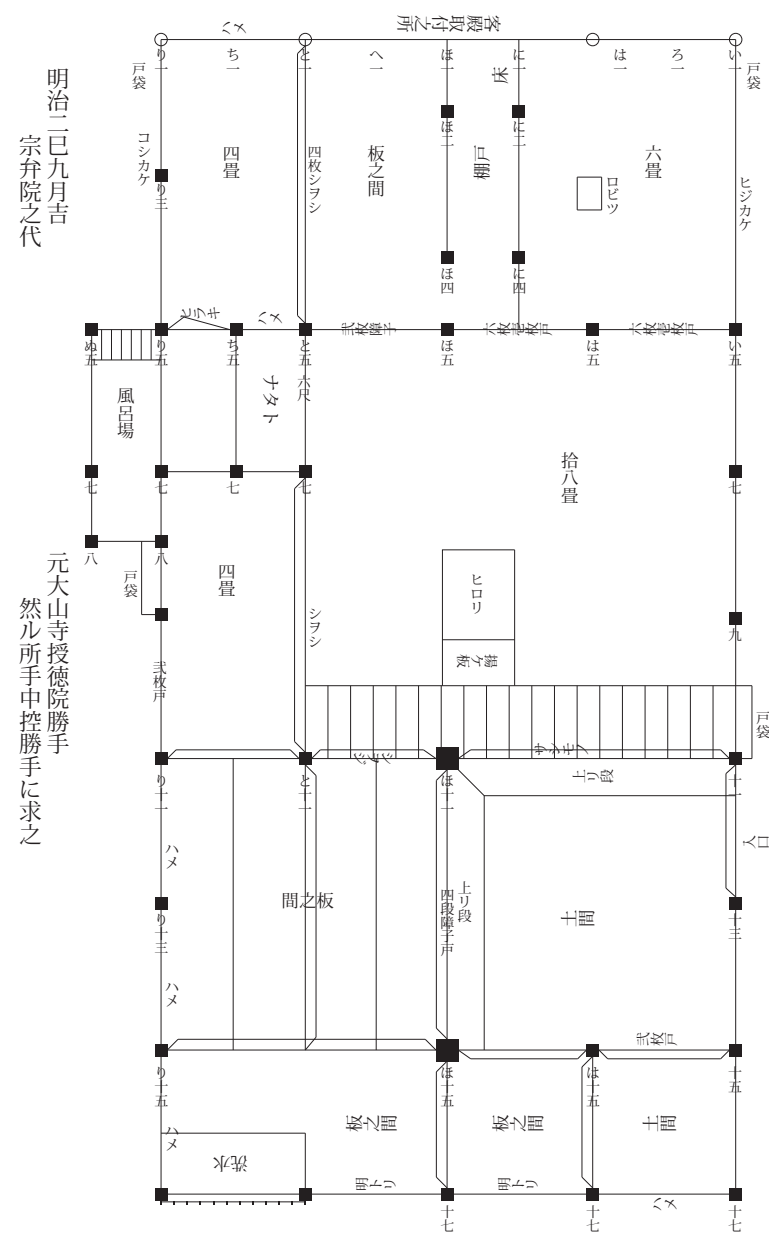

Fig.12 Floor plan of the Jutokuin mansion ${ }^{28)}$ 図 12 授得院屋敷指図 [5]

ける ${ }^{13)}$ 。目的や機能から、取次の間が出入り口の近く に配置され、訪問者が最初に訪れる場所であることは 当然といえる ${ }^{14)}$ 。仏間に至るまでに一部屋乃至数部屋 を経ることは、空間に上位と下位の階層を演出するた めであろう。例えば、大覚坊や中之院の屋敷には途中 に溜の間がある。部屋の配置と名称から、おそらくは 参詣者が建物の中に入り、まずは留まる場所であるこ とが想定される。その目的や機能は、取次の間に似る ものと考えられよう ${ }^{15)}$ 。八大坊の屋敷にみられる<使 者之間 $>$ も同様である。十二坊の屋敷には、取次の間 や溜の間などに相当する空間の必要性が認められる。

効率的に法要を行うために、檀家は玄関一溜の間・ 取次の間一次の間一上段の間－仏間を順次に移動して いっただろう。動線の形態は、八大坊のコの字型や大 覚坊の L の字型、中之院の鍵の字型及び I の字型など さまざまである。また、大覚坊や中之院では炬を備え た茶の間があり、人の流れは茶の間まで想定される。 玄関から仏間までの動線上からはずらされ、その近傍 に用意されている ${ }^{16)}$ 。

内向き空間の構成

内向きの空間は、基本的には居室空間である居間と 作業空間である土間や板敷きからなる。居間は住持等 が日常を過ごす場所と考えられるが、決して閉ざされた場所ではな

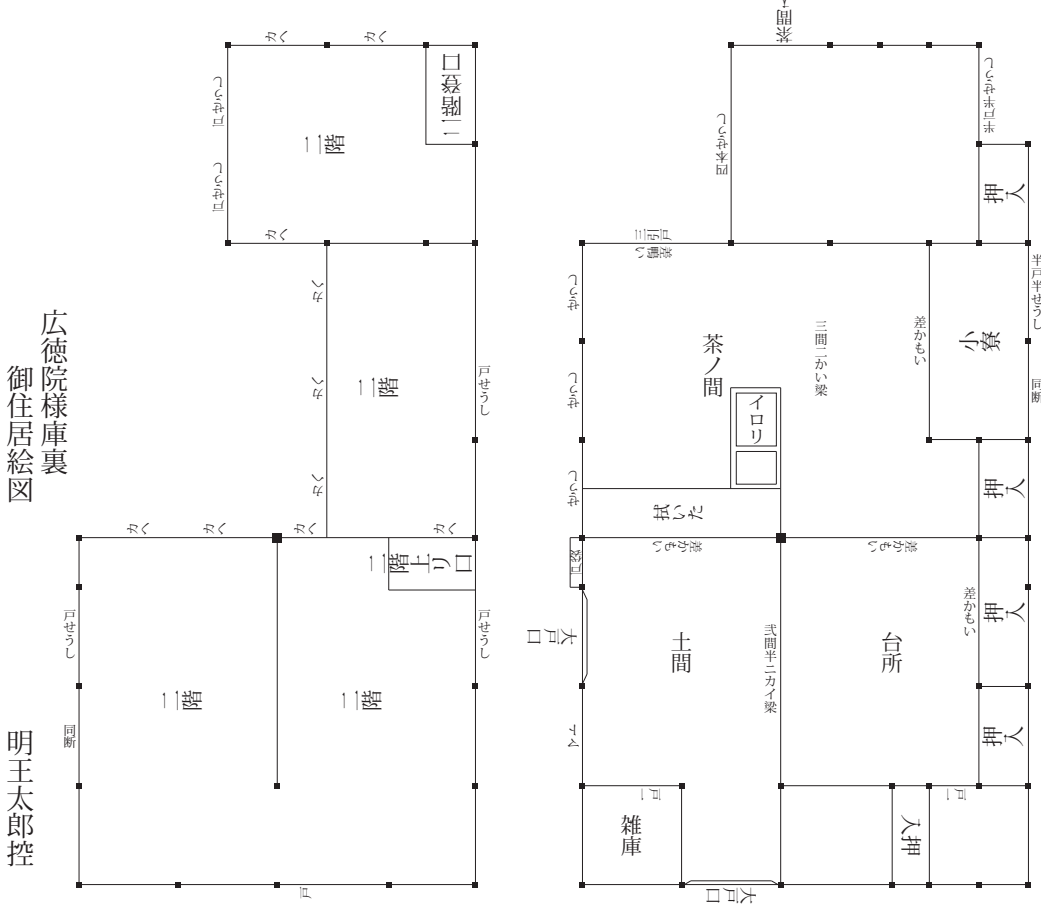

Fig.13 Floor plan of the Koutokuin mansion ${ }^{28)}$ 図 13 広徳院屋敷指図 [6]

かったようである。例えば、八大坊は居間（もしくはその付近）で 供僧や役人に食事や酒を振る舞い、止宿もさせている ${ }^{17)}$ 。また、御 


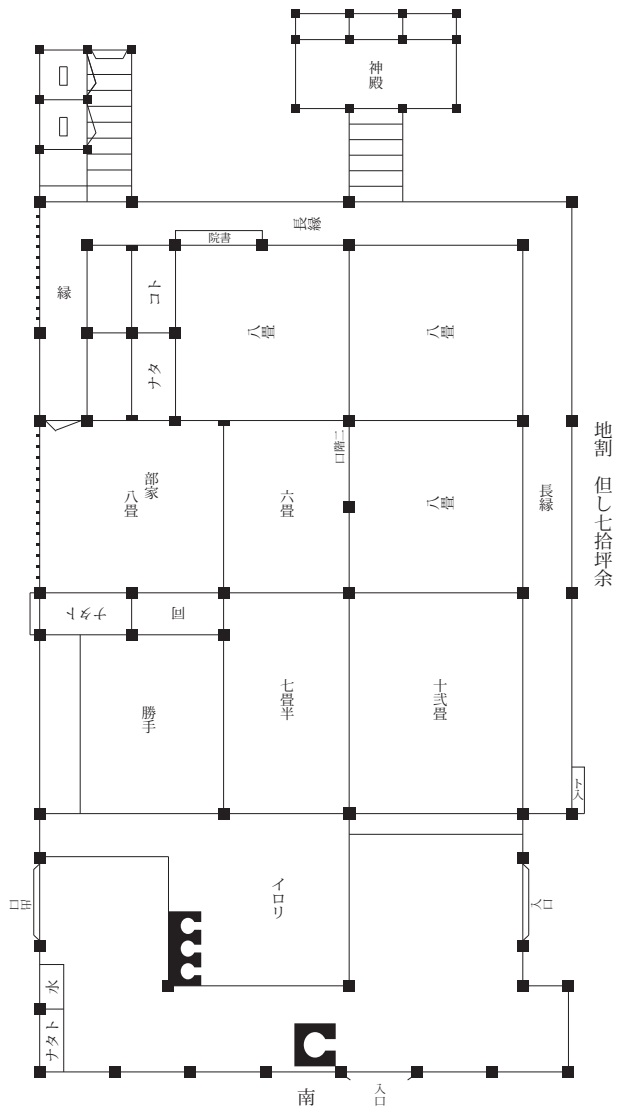

Fig.14 Floor plan of the Takao's house $\mathrm{e}^{28)}$ 図 14 高尾家住宅指図 $[7-\mathrm{A}]$

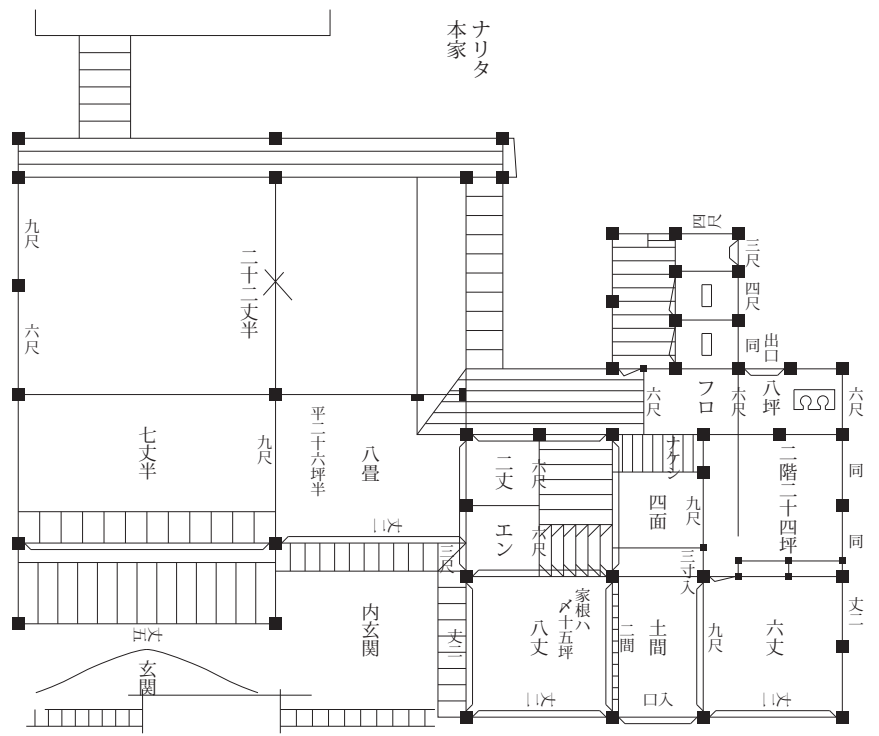

Fig. 16 Floor plan of the Narita's house ${ }^{28)}$ 図 16 成田家住宅指図［8］

師に限らず十二坊も檀家を所有していたことが知られ、多くの人数 を一度に収容するような機能が計画されていた可能性もあるだろ $j^{18)}$ 。

土間や板敷きには、炊事をするための䇴や流しを設け、炉を切り 或いは炉櫃を置く。また、これら勝手において来客の対応をしてい たと考えられ、相応に広い空間であることは共通する。檀家は土間 を介して建物の内外に出入りしていたと考えられるが、大覚坊の小 玄関は檀家の出大り口と捉えるのが自然であり、中之院の四つ目の 出大り口として個別に設けられた<中庭入口>も檀家の利用が想定
される ${ }^{19)}$ 。

$3-2$. 御師の住

宅

神殿の設置

御師の住宅には 神殿が置かれ、神 職である御師によ り祈禱などの神事 が執り行われた。 高尾家にも神殿が 設けられており、 建物とは別に建 築されている ${ }^{20)}$ 指図には小規模な 祠として描かれて いるが、仕様書に は＜仮神殿五坪> とも記されてお り、仮設によると も考えられる ${ }^{21)}$ 成田家にも神殿は 設けられていたで あろうが、位置は 特定できない。仮 に高尾家と同じと

Fig.15 Floor plan of the Takao's house ${ }^{28}$ 図 15 高尾家住宅指図 [7-B]

するならば、縁に接続する渡り廊下の先にあると考えられ、指図か ら判断すると規模が大きい。

勝手の機能

御師が果たすべき役割の一つに、檀家等の参詣者に対する山内の 案内が挙げられる。山開きの短期間に集中して登拝する人数は膨大 で、各々の御師が所有する檀家も相当数に上り、例えば、村山家に は天保 2 年 (1831) の夏山の間に合計 855 名が滞在した（表 1） ${ }^{22) 。 ~}$ 中には＜昼通り>として宿泊しない客もいたであろうが、多くは宿 泊していったと考えられ、連泊する者もあった。また、同家の年中 行事を記録した「村山年中行事」によると、大祭中に<主人・内方・ 手代・料理人・下女・下男・飯炊 $>$ の各人が仕事を分担し、主人や 手代の役割から、参詣者が到着して出立するまでの大凡の行動が知 れる ${ }^{23)}$ 。特に、到着の段階で仕事が多く、まずは主人と手代で出迎 え講中や姓名を記帳し、荷物や履き物に札を付け、諸々の祈願を受 け付ける。また、坊入や札など料金の支払い、本社での祈禱の取り 次ぎ、土産札・神札の購入など、参詣者の応対は多く帳場で行われ た ${ }^{24)}$ 。つまり、入口を備えた勝手で滞在者に応接していた。

$3-3$. 屋敷と住宅

\section{入口と出口}

十二坊の屋敷にはいずれも玄関が設けられていたが、御師の住宅 にはない場合もあり、十二坊と御師の社会階級などの差異を反映し ている。一方で、高尾家・成田家の住宅では共に入口と出口が個別 に設けられており、十一坊の屋敷は多く入口のみであるが、八大坊 の屋敷は出口もある点で共通する。大る場所と出る場所を明確に区 別しており、つまりは人の動きが単一の方向に規定され、動線を効 
Tabel 1 The number of visitors at Murayama's house

表 1 村山家に滞在した檀家等の人数

\begin{tabular}{|c|c|c|c|c|c|c|c|c|c|c|c|c|c|c|c|c|c|c|c|c|c|c|c|c|}
\hline \multirow{2}{*}{$\begin{array}{l}\text { 月日 } \\
\text { date }\end{array}$} & \multicolumn{5}{|c|}{6 月 June } & \multicolumn{18}{|c|}{ 7月 July } & \multirow{2}{*}{$\begin{array}{l}\text { 合計 } \\
\text { total }\end{array}$} \\
\hline & 26 & 27 & 28 & 29 & 30 & 1 & 2 & 3 & 4 & 5 & 6 & 7 & 8 & 9 & 10 & 11 & 12 & 13 & 14 & 15 & 16 & 17 & 18 & \\
\hline $\begin{array}{c}\text { 人数 } \\
\text { number of visitors }\end{array}$ & 11 & 67 & 81 & 39 & 15 & 40 & 80 & 45 & 60 & 22 & 68 & 29 & 35 & 27 & 4 & 26 & 6 & 24 & 12 & 111 & 45 & 7 & 1 & 855 \\
\hline
\end{tabular}

率的に計画していることになろう。また、入口と出口は土間を介し ていることや、出口はそのまま敷地の外へと導かれるように置かれ ることなどが、傾向として指摘できる。

宿泊の機能

御師の住宅に要求される機能の一つとして、参詣者が宿泊する場 所の提供がある。檀家等を自宅に宿泊させて収入を得ることは、御 師の活動を成立させる重要な基盤でもあった ${ }^{25)}$ 。高尾家や成田家に は二階が作られており、宿泊に利用されていたことが想定される ${ }^{26) 。}$

十二坊屋敷の内で、檀家を所有していた大覚坊や広徳院の屋敷に は二階が存在した。特に、後者では二階部分の指図が残されており、 間取り等が知れる。部屋名が記述されておらず用途は不明ながら、 宿泊のために利用されていた可能性もあろう。

\section{4. 屋敷と住宅の内部空間構造}

近世相模国大山寺の寺内や門前に建てられた十二坊の屋敷や御師 の住宅の復元と特徴の分析を目的に、史料の収集・読解・分析を行っ た。その結果、屋敷や住宅に特徵的な要素と、相互に影響を及ぼし ている要素を指摘することができた。

十二坊の屋敷は座敷や勝手など表向きと内向きの部分に区別され、 それぞれの内部空間に対応する出入り口が設けられた。護摩などの 法要が行われる仏間から玄関までに諸室が接続し、途中には取次の 間や溜の間と呼称される部屋もみられる。手前から奥へと明確に空 間の階層を設定すると同時に、部屋の構成で進入の経路を規定し動 線を操作していた。御師の住宅に用意される勝手は帳場として参詣 者を応対する場となり、個別に設けられた入口と出口は円滑な移動 が目論まれ効率的である。いずれも短期間に多くの宿泊者が訪れる 宿坊であることを反映している。

十二坊の屋敷と御師の住宅は双方に影響を与えていることが想定 され、両者の共通点を指摘することができる。例えば、十二坊の屋 敷の中には広い勝手や大口と出口が個別に設けられるなど、御師の 住宅と同じように参詣者の来訪が考慮されていた。反対に、御師の 住宅にも座敷飾りを備えた座敷を最深に幾つかの部屋を接続させて 空間に階層がみられ、規模は小さいながらも十二坊の屋敷と同じ特 徵を有している。一方で、十二坊の屋敷と御師の住宅の相違点も挙 げられる。例えば、十二坊の屋敷では座敷の最奥が仏間となり、仏 壇や須弥壇が置かれ、護摩などの祈䘠が行われた。一方で、御師の 住宅には仏事ではなく神事を行うための施設が備えられ、縁を介し て独立した神殿が設けられていた。僧侶と神官という職種の差が屋 敷や住宅の設備から読み取ることができ、明確な違いとして現れて いる ${ }^{27)}$ 。

以上を要するに、改めて大山寺の寺内や門前にある十二坊の屋敷 や御師の住宅は、大山参りという歴史的・社会的な現象を踏まえた 建物であることが指摘できる。

注

1）鈴木章生「相模大山の慶長山内改革について」『立正史学』第 60 号、立正 大学史学会、1986.9、pp.21～35。別当の八大坊だけでなく、供僧とし て大覚坊・上之院・中之院・常円坊・橋木坊・宝寿院・実城坊・授得院 養智院・広德院・喜楽坊の十一坊が置かれ、十二坊と総称された（内海弁 次『相州大山』、神奈川新聞社、1996.10、pp.223～224)。

2)『大山史』第 4 編 近古史・第 21 章 實雄法印」(石野瑛 編『相模大山縁起 及文書』、名著出版、1973.11、pp.55～61)。

3）御師に関しては、田中宣一「相州大山講の御師と檀家 江戸未期の談廻と夏 山登拝をめぐって」(『日本常民文化紀要』第 8 号 II、成城大学大学院文学 研究科、1982.3、pp.157〜 191）などが、檀家に関しては、有賀密夫「大 山門前町の研究 門前町の形成と御師の活動と檀家圈」『地域研究』第 14 号、 立正地理学会、1971.6、pp.17～28）などがあり、これら二編を含めた 大山信仰に関する代表的な論考は、圭室文雄 編『民衆宗教史叢書 第 22 巻 大山信仰』(雄山閣出版、1992.8）に編集されている。

4）『秦野市史民俗調査報告書 3 漂白と定住・御師の村』、秦野市、1984.3、 pp. $82 \sim 124$ 。

5）松岡俊「相模大山御師の檀家集積過程の構造 村山八太夫直利と八大坊預 置檀家を中心として」(『伊勢原の歴史』第 11 号、伊勢原市、1996.3、 pp.49〜65) では、檀家を「財」と見なしている。財である檀家は、流 通・交換・集積などの経済活動を通じて、御師の間を流動したという。ま た、同「コミュニケーション的行為としての「檀迴」相模大山御師村山八 太夫の檀迴を中心として」(『伊勢原の歴史』第 12 号、伊勢原市、1997.3、 pp.35 44）でも、御師が檀家を回る「檀迴」に注目し、同様の検討を行つ ている。

6）川島敏郎『相州大山信仰の底流 通史・縁起・霊験譚・旅日記などを介して』、 山川出版社、2016.1、p.50。

7）地域の旧家に伝わる古文書を具体的な調査・研究の対象として、主に以下 の史料群を用いる。

「手中家資料」は、大山を拠点に活動した大工棟梁の手中家に伝わる史料 群である。原本は、神奈川県立公文書館に寄託されている。史料は整理・ 分類され、詳細な目録が作成された (『相模国大山大工棟梁手中家資料所 在目録稿』神奈川県教育委員会、1997.3)。明王太郎に関しては、手中正「手 中明王太郎と大工文書そして明王太郎敏景」(『伊勢道中日記 旅する大工棟 梁』、平凡社、1999.11、pp.123～190）にまとめられている。歴代の棟 梁は「明王太郎」を襲名し、由緒は古く近世以前に遡るが、史料からは主 に江戸時代の活躍を知ることができる。また、寺内や門前の堂社や住宅の 建築も数多く手掛けたようであり、八大坊や十一坊などの屋敷や御師の住 宅に関する史料が含まれている。建築を専門にした職人による史料という こともあり、建物の内容を詳細に知ることができる。

「高尾勲家文書」は、大山に居住した御師の高尾家に伝わる史料群である。 原本は、かつて当家に所蔵されていたが、その後は所在不明のようである (2009 年現在、伊勢原市からの聞き取りによる)。これまでに伊勢原市が 市史編さんの一環として同資料の調查を行っており、史料の複写と目録の 作成が行われた。複写物は伊勢原市役所に所蔵され、目録は伊勢原市総務 部市史編さん室 編『伊勢原市史資料所在目録 2』（伊勢原市、1988.3）に 揭載されている。檀家を書き上げた檀家帳が主な内容であるが、居宅を新 築した際の史料も含まれて扔り、御師の住宅に関する情報を得ることがで きる。

8）寺院内に営まれる子院の建築に関して、これまでにも多くの研究が行われ ている。例えば、杉山信三『院家建築の研究』（吉川弘文館、1981.9）や 川上貢『禅院の建築 禅僧のすまいと祭享』（河原書店、1968.1）を始め、 鈴木嘉吉『古代寺院僧房の研究』（中央公論美術出版、2016.4）や高田良 信『法隆寺子院の研究』（同朋舎出版、1981.8）の他に、伊坂道子『芝増 上寺境内地の歴史的景観 その建築と都市的空間』（岩田書院、2013.10） などが挙げられる。中でも後ろの二書はいずれも寺院組織の役職の差異が 建築に反映していることを論じて扔り、近世に扔ける子院を考察する上で 示唆に富む。特に、増上寺に扔ける職掌の一つである坊中の建築は、「客 殿（仏間）および庫裏と思われる一対の空間をもつ」（前掲書、p.90）こ とや、「敷地の形状や接道位置に合わせて、宿坊のための付加的な座敷、 中庭などが連なっている」(同書、p.91) ことなどが特徴として指摘され ており、十二坊の建築を理解する上で参考となる点が多い。 
また、大山の御師の住宅に関して、伊勢原市史編集委員会 編『伊勢原市史 民俗調査報告書 3 伊勢原の民俗 大山地区』（伊勢原市、1990.3、pp.114123）や、小沢朝江・小林純志「相模国大山門前町における御師住宅の平面 と変遷 伊勢原市大山門前町の調査研究 (2)」(『日本建築学会大会学術講演 梗概集』、日本建築学会、2008.7、pp.93～94）などの先行研究がある。 更に、他の地域の御師の住宅に関して、例えば伊勢や富士を対象とした先 行研究がある。特に、外川家住宅学術調查会・富士吉田市歴史民俗博物館 編『富士山吉田口御師の住まいと暮らし 外川家住宅学術調査報告書』(富 士吉田市教育委員会、2008.3）では詳細な報告と論考が収められて打り、 御師の住宅の平面構成を都市の構造や地割との関係から竪家と横家の差異 で把握し、祭祀空間を中心とする座敷の構成が定型化した上で玄関から御 神前・御神殿までの軸線が確立することなどを明らかにしている（同書、 pp.128 136)。

9）御師の住宅を考察する上で、「取次間」は主要な研究課題の一つである（松 岡俊「相模大山寺の「取次」制度の構造 媒介する宗教者の取次をめぐって」 『秦野市史研究』第 16 号、秦野市、1996.3、pp.23〜 42)。「取次間」が 注目されたのは、大山には「取次」という制度が存在するためである。大 山は近世初頭に結界がはられ、山上は聖域と定められたために、修験者は 御師となって門前町に居住するようになったという経緯がある。御師は大 山寺と檀家の中間に位置し、両者を結ぶ役割を担うようになる。この仕組 みが制度化されたのが「取次」であり、「取次間」も単に人と人の間を仲 介するという一般的な意味ではなく、大山に固有の制度を反映した名称で あり用途であって、御師の機能を象徴する空間であることが指摘された。

10） 1 - A：「八大坊様上寺地割控又百十四坪」(手中家資料〈3924〉)。

$1-\mathrm{B}$ : 「八大坊様上屋敷敷地割」(手中家資料〈2942〉)。

$2-\mathrm{A}$ ：「大山寺大覚坊普請註文書（絵図とも）」(手中家資料〈3250〉)。 同史料は、伊勢原市史編集委員会 編『伊勢原市史 資料編続大山』（伊勢原 市、1994.3、pp.113〜 123）に翻刻されている。

$2-\mathrm{B}$ : 「大山寺大覚坊様御客殿地割」(手中家資料〈684〉)。

$2-\mathrm{C}:\lceil$ 大山大覚坊様御客殿地割」(手中家資料〈682〉)。

$2-\mathrm{D}$ ：「大山寺大覚坊様地割」(手中家資料〈2958〉)。

3-A：「照海様代中之院様地割図」(手中家資料〈634〉)。

$3-\mathrm{B}$ : 「大山寺中之院様客殿地割」(手中家資料〈690〉)。

3-C :「中之院様地絵図扣」(手中家資料〈3270〉)。

$4: 「$ (元大山寺常円坊勝手平面図 $) 」($ 手中家資料〈2967〉)。

5 :「元大山寺授得院勝手」(手中家資料〈801〉)。

6 :「広徳院様庫裡裏 御住居絵図」(手中家資料〈3925〉)。

$7-\mathrm{A}$ : 「家作仕様積立帳」(高尾家資料〈49〉)。

$7-\mathrm{B}$ : 「家作仕様積立帳」(高尾家資料〈51〉)。同史料は、伊勢原市史編 集委員会 編『伊勢原市史資料編続大山』（伊勢原市、1994.3、pp.98～100） に翻刻されている。

8 : 「出火万控」(手中家資料〈591〉)。同史料は、伊勢原市史編集委員会 編『伊 勢原市史 資料編続大山』（伊勢原市、1994.3、pp.432～473）に翻刻さ れている。

各指図におけるグレ一部分は朱書きを示す。なお、同時期に多数の指図が 作成されたのは、安政元年 (1854) の火災で多くの堂舎・住宅が焼失し、 再建が計画されたためである。一方で、復興は容易でなく、数年の歳月が 掛かり、そのまま明治維新を迎えることとなる（内海弁次『相州大山』、 神奈川新聞社、1996.10、pp.238〜 239)。

11）寺院内のいわゆる子院の建築における堂と庫裏に当てはめて理解すること ができる（高田良信『法隆寺子院の研究』、同朋舎出版、1981.8、p.26）。

12）中間に位置する出入り口として、八大坊では「内玄関」が、大覚坊では「小 玄関」が、中之院では「中庭入口」が、それぞれ該当する。例えば、「内玄関」 が表向きではない内向きのための玄関 (内向きの空間に通じる) であり、「小 玄関」が正式ではない略式の玄関（表向きの空間に通じる）である、とい う一般的な理解に加えて、どちらの空間へも通じ得る中間的な領域と位置 付けている。

13) 武州山崎村（埼玉県深谷市山崎）からの参詣者である長治郎は、上屋敷に て護摩の法要を受けたのちに宿坊へ立ち寄っている（伊勢原市史編集委員 会編『伊勢原市史資料編続大山』、伊勢原市、1994.3、p.334）。

14) 松岡俊「相模大山寺の「取次」制度の構造 媒介する宗教者の取次をめぐっ て」(『秦野市史研究』第 16 号、秦野市、1996.3、p.30) では、「ここ（引 用者注：こことは「取次間」やそれに類する部屋）に先ず案内された後に 一連の行事が進行していた」と位置付けられており、聖域と俗域や寺院と 檀家を媒介するための空間が必要であったことを指摘している。

15) 江戸城には「溜間」があるものの、将軍の側近が詰める部屋として利用され、 用途は異なる（松尾美恵子「大名の殿席と家格」『徳川林政史研究所 研究
紀要 昭和 55 年度』、徳川黎明会、1981.3、pp.301～328)。

16) 例えば、檀家を迎える重要な接待の空間として茶の間を位置付けることも できよう。

17）大山寺が幕府から朱印を授与される一件で、供僧の十一坊や目代・目付・ 名主などの役人が八大坊の上屋敷に集合するに際し、居間が使われている （伊勢原市史編集委員会 編『伊勢原市史資料編続大山、、伊勢原市、1994.3、 p.634)。

18）天明 6 年（1786）に作成された「大山寺社稷丸裸」より、八大坊・大覚 坊・喜楽坊・広徳院・宝寿院・中之院のそれぞれが檀家を所有していたこ とが分かる（伊勢原市史編集委員会 編『伊勢原市史 資料編続大山』、伊勢 原市、1994.3、p.86)。

19) 指図 $[3-\mathrm{A}]$ では<小玄関>が用意されているものの、指図 $[3-\mathrm{B}]$ では撤去されている。つまり、〈小玄関>が担っていた機能は、他の装置 が代替することになる。その一つに＜中庭入口＞が見込まれ、檀家の出入 り口としての機能を果たし得たと考えられる。

20）伊勢原市史編集委員会 編『伊勢原市史民俗調査報告書 3 伊勢原の民俗 大 山地区』（伊勢原市、1990.3、p.121）には、昭和63 年（1988）度に行 われた大山地区の建物調查の結果報告が、調査員の新井清により行われて おり、「一般民家との相違点として、まず第一に神殿があることであろう。 この神殿には大山阿夫利神社の分霊を扔祀りしている。先導師（引用者註： 御師のこと。明治維新後、御師は先導師となる）は神官であり、自宅に神 殿を造り祀っている。そして阿夫利神社の神徳を多くの人々に知らしめ、 信仰を進めるのが大きな目的である神殿の位置は大きく二つに分けられ る。その一は、ゲンカンを入った正面奥に祀られている例は、C、E、D（引 用者註:調査は五棟の先導師の建物が選定されて行われ、それぞれに A・B・ C・D・Eの記号が振られた）の各家で、そのうちD家では現在では二階 に移してあるが、元の位置に戻すとこの類になる。これは講社の人達が参 扯のため訪れた時、先づ神殿へ拝礼をするに良い位置である。また阿夫利 神社の大祭中は、ゲンカンへ仮の祭殿を設け、神を祀ることが行われてい る」として、当時において神殿は玄関に置かれたという。また、小沢朝江・ 小林純志「相模国大山門前町に扔ける御師住宅の平面と变遷 伊勢原市大山 門前町の調査研究 (2)」(『日本建築学会大会学術講演梗概集』、日本建築 学会、2008.7、pp.93〜 94) でも、「神殿は、(中略) 入口正面の部屋に 置き」と同様の指摘がある。一方で、高尾家に玄関はなく、成田家も神殿 を設置する場所が玄関にはみられない。

21)「家作仕様積立帳」(高尾家資料〈51〉)。

22）伊勢原市史編集委員会 編『伊勢原市史資料編続大山』、伊勢原市、1994.3、 pp.323 367。

23) 例えば、主人の役割として<御着挨拶、坊入記録、講中札包、食事挨拶 $>$ が、手代の役割としてく御着受付、荷物札付、履物札付、姓名記帳、諸祈 願受付、御立ノ節着札渡、諸事気ヨ付べシ＞が、それぞれ列記されている （伊勢原市史編集委員会 編『伊勢原市史資料編続大山、、伊勢原市、1994.3、 pp.819 820)。

24) 参詣者への案内である「大祭中座敷張札扣」には、「坊入御札料其他、総 て金銭八直接二帳場へ御持参被下度候也」や「御本社ノ御祈禱御願ヒノ方 八帳場へ御申込可被下、願書認义御取次申候也」と記されていた（伊勢原 市史編集委員会 編『伊勢原市史資料編続大山』伊勢原市、1994.3、p.823)。

25）大山の麓に位置する子易村で旅人を宿泊させることに対して、御師が訴訟 を起こしている（伊勢原市史編集委員会 編『伊勢原市史 資料編近世 1』、 伊勢原市、1992.3、pp.492-495)。

26）二階に「客用の宿泊室」を用意することが一般的であったようである（伊 勢原市史編集委員会 編『伊勢原市史民俗調査報告書 3 伊勢原の民俗 大山 地区』（伊勢原市、1990.3、p.121）。

27）な扔、十二坊の中でも別当である八大坊と他の供僧である十一坊の屋敷で は、寺院組織内の身分の差を反映した違いが想定される。例えば、八大坊 の屋敷にみられる車寄せや唐破風は比較的に大きく描かれ、或いは十一坊 の屋敷にのみ表向きの空間に茶の間が設けられるなど、指摘し得る点はあ るものの断言するにはな抩史料が不足しており、付記するにとどめる。

28) These plans writen by Japanese because of the old documents traced.

\section{図版出典}

図 1 : 内海弁次『相州大山』、神奈川新聞社、1996.10

図 2 13、16: 手中家資料より著者作成

図 $14 \cdot 15$ : 高尾家資料より著者作成

付記

•本稿は、JSPS 科研費（課題番号：17K14796）による研究成果の一部である。 


\title{
EARLY-MODERN ARCHITECTURE FOR JUNI-BO AND OSHI IN OYAMA-DERA TEMPLE OF SAGAMI-NO-KUNI PROVINCE
}

\author{
Yoshihiro YAMAGISHI ${ }^{* 1}$ \\ ${ }^{* 1}$ Assist. Prof., College of Engineering, Nihon Univ., Dr.Arch.
}

M t. Oyama, also called A furi-yama (rainfall mountain), is located at the east end of Tanzawa-sanchi mountains in the central west part of Kanagawa prefecture. The foundation and origin of the temple and shrine can be traced back as far as ancient times. In the early-modern times, the temple was revived under the patronage of the Tokugawa government so that a management organization was formed for autonomy, composed of Hachidai-bo (eight great monks) and J uni-bo (twelve branch temples). At the same time, M t. Oyama was determined as a sacred precinct, so Shugenja (mountain ascetics) had to leave the temple to be "Oshi (priests)" and lived along the approach to the temple forming a Monzen-machi (temple town). The precinct and the temple town developed with the series of Tokugawa leyasu's "Sannai-kaikaku (precinct reformation)" until the end of Edo period. The greatest feature of M t. Oyama in the Edo period was that "Oyama-mairi (visiting Oyama)" by Oshi and Danka (patron household) won popularity throughout the $\mathrm{K}$ anto region. At its peak, around a million of people were said to believe in the mountain, organizing $\mathrm{Ko}$ (associations) in different parts of the region to make vicarious visits to the temple. They were called "Danka (patron household)" and traveled to the temple with the guidance of a specific Oshi. In addition to providing lodging, visiting Dankas' houses that were scattered throughout the Kanto region one by one to offer Ofuda (talismans) and prayers was Oshi's another function. They developed routes that connect different areas with Oyama, and stayed at a specific Dankas' house to make their round. In this way, both Oshi and Danka traveled over a wide area to make a dynamic social structure function. O shi acted as an intermediary between the temple and the Danka. They served under the Oyama-dera temple and located between the sacred precinct and the secular society.

This paper aimed to recover the outline and analyze the characteristics of the mansions of J uni-bo (twelve branch temples) in Oyama-dera temple precinct and the houses of Oshi in its temple town by collecting and comprehending relative historical materials. It focused on the second half of the Edo period, when "Oyama-mairi (visiting Oyama)" became prosperous, through the end of Edo and the beginning of M eiji periods to give a consideration from the perspective of architectural history.

Consequently, it was indicated that the mansions and the houses had their own characteristics along with interactive elements. The J uni-bo mansions were divided into outward and inward parts. A midway area was also recognized. Three doorways of the front, side, and service entrances reflected the existence of each interior space. Several rooms joined the Butsuma (altar room), where Buddhist services were practiced, to the front entrance, and a Tamari-no-ma (anteroom) was also laid out in between. Spatial hierarchy was thus clearly set from the front to the back, and the configuration of the rooms regulated the approach route to control the path of flow. On the other hand, Oshi's houses contained a large kitchen space as an office to deal with pilgrims, and the entrance and exit were separated to ensure smooth and effective flow. Each function reflected the fact that the buildings were Shuku-bo (pilgrims' lodgings) that accommodated many visitors in a short period of time. At the same time, the Juni-bo mansions also had a large kitchen space and separate entrance and exit, taking pilgrims visit into account. Likewise, Oshi's houses also had a Zashiki (tatami room) at their innermost with several rooms joined to produce spatial hierarchy. Thus it can be said that the elements of the mansions and the houses interacted each other. 